\section{Protests over Einstein statue}

A proposal by the US National Academy of Sciences to erect a 21-foot statue of Albert Einstein in its Washington grounds has run into a storm of protest from members of both the academy itself and of the local Washington community.

Several physicists have complained that at a time when basic science is being squeezed for funds, it is inappropriate for the academy to be seen spending \$1.5 million on the statue, and that Einstein himself would have preferred the money to have been spent on some scientific endeavour.

Others have pointed out that Einstein repeatedly asked that he should not be treated as a cultural hero. And comments on the design of the statue in the local press have ranged from "a blunder of mediocrity" to "the latest disgrace to our city".

The decision to erect the statue as part of this year's centennial celebrations of Einstein's birth was announced two months ago by Dr Philip Handler, president of the academy. According to Dr Handler, the large size of the bronze statue--which together with its marble base will weigh 139 tonsrepresents that fact that Einstein was "a giant among men".

The sculpture is the work of artist Robert Berks, who sculpted a head of the physicist in 1953. He had previously proposed unsuccessfully a full-length statue to the Weizmann Institute in Israel, to Princeton University, and to the Smithsonian Institution in Washington.

The academy has written to all its members, as well as other members of

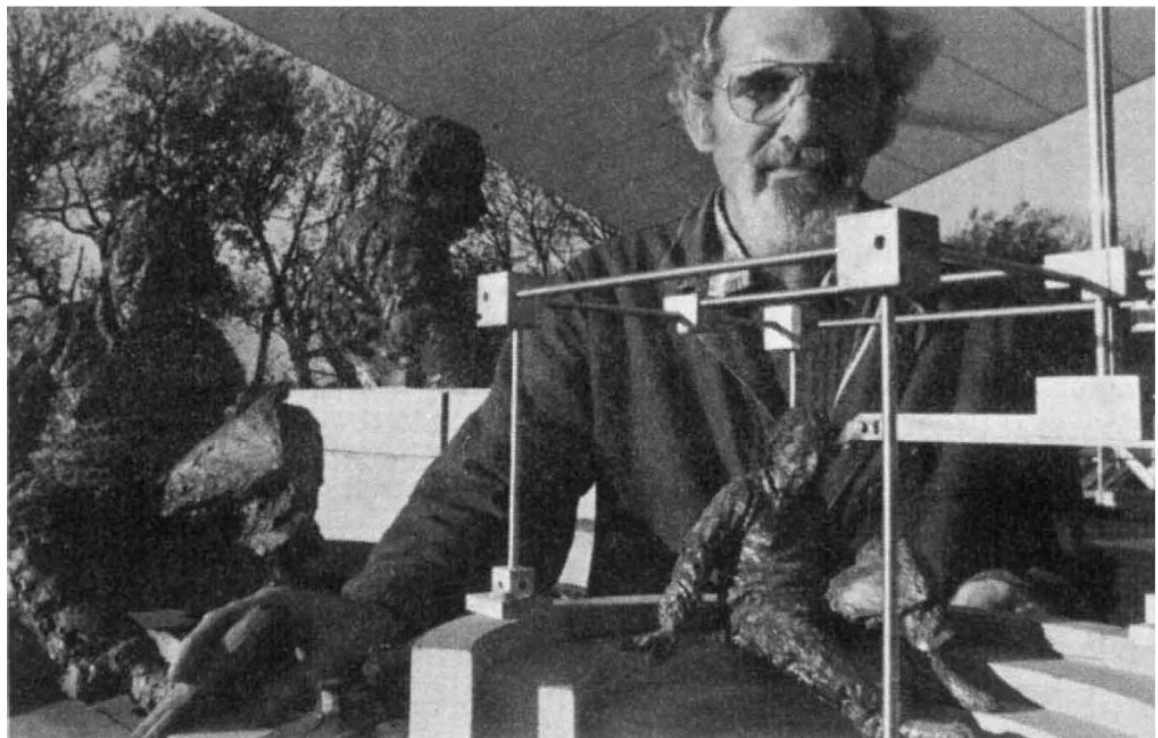

Sculptor Robert Berks with models of the controversial statue

the scientific and technical community, requesting financial support for the project. But while some have been pleased to contribute-over 2,000 contributions have so far been receivedothers are less happy.

"There are a number of people here who almost hit the ceiling when they were asked to contribute to the statue. So far I have not heard a favourable word from anyone on the scheme," a physicist at one West coast university said last week.

Another complained that the decision to erect the statue had "simply arrived out of the blue", and that although the proposal had initially been put to and accepted by an annual meeting of the academy, there should have been wider discussion among members.

In Washington, opposition to the statue has been expressed mainly in the pages of the Washington Post. Fol- lowing a critical article by one of the newspaper's contributors, a number of readers wrote in voicing objections.

Commenting on the large scale of the statue, for example, one correspondent wrote that "If anything concise may be said about Einstein's life, it is that he was a philosopher of mathematical precision and theoretical proportion". The Post itself joined in the fray with an editorial complaining that the statue "doesn't honour its subject", and suggesting that the academy should "start again".

A spokesman for the NAS said last week that the academy had not yet decided whether to reply to the criticism made in the Post, and pointed out that a large number of favourable comments about the statue-including its initial approval by Washington's Commission of Fine Arts-had been received.

David Dickson

\title{
AAAS to assist China with the popularisation of science
}

AN agreement opening the way to joint activities on the popularisation of science and on science education has been reached between the American Association for the Advancement of Science and the Scientific and Technical Association (STA) of the People's Republic of China.

The agreement, which is expected to lead to increasing co-operation at the nongovernmental level between the two organisations, was worked out during a visit to China last month by a 12person delegation from the AAAS.

In particular, the agreement provides for a return visit by the Chinese to the US next spring, and for the AAAS to identify US specialists willing to visit China to lecture on topics specified by the STA.

Announcing these moves in Washing- ton on the AAAS delegation's return, Mr Emilio Q. Daddario, chairman of the association's board of directors, said that various Chinese ministers had given their approval to such an agreement, and that President Carter's announcement of the normalisation of diplomatic relations between the two countries "cannot but help to make our agreement more meaningful."

Mr Daddario also said that the Chinese were contemplating sending a special misssion to the US to look at various ways in which science is "popularised". Such a visit might include talks with science journalists, and visits to science museums and technical information centres.

"During the Cultural Revolution there was a sense in China that science produces an intellectual elite. Now they want to make it clear to the masses that science has benefits for people, and that it is important that they should understand it", said Mr William Carey, executive officer of the AAAS.

"The Chinese want to get people in the streets, in the farms and in the factories to support the thrust towards modernisation in the fields of science and technology. And they have a very great appetite for US experts to go and give lectures, a method they are seizing upon to get a quick turn-around on their scientific efforts."

Mr Carey said that the Chinese had expressed interest in working with the AAAS on various aspects of science education, in particular the development of curricula for university and higher education.

David Dickson 